\title{
Proliferation Activity in the Adult Rat Brain Following Exposure to lonizing Radiation
}

\author{
Proliferačná aktivita $v$ dospelom mozgu potkana po expozícii \\ ionizujúcim žiarením
}

\author{
Bálentová S. ${ }^{1}$, Hajtmanová E. ${ }^{2}$, Trylčová R. ${ }^{4}$, Lehotský J. ${ }^{3}$, Adamkov M. ${ }^{1}$ \\ 'Institute of Histology and Embryology, Jessenius Faculty of Medicine, Comenius University, Martin, Slovak Republic \\ ${ }^{2}$ Department of Radiotherapy and Oncology, Martin University Hospital, Martin, Slovak Republic \\ ${ }^{3}$ Institute of Medical Biochemistry, Jessenius Faculty of Medicine, Comenius University, Martin, Slovak Republic \\ ${ }^{4}$ Jessenius Faculty of Medicine, Comenius University, Martin, Slovak Republic
}

\begin{abstract}
Summary
Background: The aim of our study was to investigate radiation-induced short-term effects on the rat forebrain. Material and Methods: Adult male Wistar rats received whole-body exposure with fractionated doses of gamma rays (a total dose of $3 \mathrm{~Gy}$ ) and were investigated seven and 14 days later. Immunohistochemistry and confocal microscopy were used to determine proliferating cells derived from anterior subventricular zone (SVZa) and distributed along the subventricular zone-olfactory bulb axis (SVZ-OB axis). Cell counting was performed in four anatomical parts along the well-defined pathway, known as the rostral migratory stream (RMS) represented by the SVZa, vertical arm, elbow and horizontal arm. Results: Different rate of cell overdistribution was found in all counted parts through the entire experiment, mostly detectable in the elbow and horizontal arm. Conclusion: Results suggested that radiation response of proliferating cells resides the SVZa may a play contributory role in the development of more adverse radiation-induced late effects.
\end{abstract}

\section{Key words}

ionizing radiation - dose fractionation - brain - SVZ-OB axis - Ki-67

\section{Súhrn}

Východiska: Ciel'om práce bolo skúmat' krátkodobé účinky ionizujúceho žiarenia na predný mozog potkana. Materiál a metodika: Dospelé samce kmeňa Wistar sme ožiarili celotelovou frakcionovanou dávkou gama žiarenia (celková dávka bola 3 Gy) a vyšetrovali sedem a 14 dní po expozícii. Pomocou imunohistochemického farbenia a konfokálnej mikroskopie sme detekovali proliferujúce bunky pochádzajúce z prednej steny subventrikulárnej zóny (SVZa) a následne migrujúce pozdĺž osi subventrikulárna zóna - bulbus olfactorius (SVZ-BO). Počet proliferujúcich buniek sme detekovali v štyroch anatomických oblastiach pozdĺž vopred definovanej migračnej trasy, známej ako rostrálna migračná dráha (RMS) t.j. v SVZa, vertikálnom ramene, ohybe a horizontálnom ramene. Výsledky: Vo všetkých hodnotených oblastiach sme počas trvania experimentu zaznamenali rôzny stupeň zvýšenej distribúcie proliferujúcich buniek, a to najmä v ohybe a horizontálnom ramene. Záver: Výsledky naznačujú, že postradiačná odpoved' proliferujúcich buniek, ktoré sa podielajú na bunečnom zložení SVZa môže zohrávat' úlohu vo vývoji neskorých postradiačných prejavov, ktoré sú z hladiska prognózy vel'mi nepriaznivé.

\section{Klúčové slová}

ionizujúce žiarenie - frakcionácia dávky žiarenia - mozog - os SVZ-BO - Ki-67

\begin{abstract}
This work was supported by a VEGA grant 1/0050/11 and project 'Center of excellence for research in personalized therapy (CEVYPET)', code: 26220120053 and 'Identification of novel markers in the diagnostic panel of neurological diseases' co-financed from EU sources and the European Regional Development Fund.

Práca bola podporená grantom VEGA 1/0050/11 a projektami „Centrum excelentnosti pre výskum $\checkmark$ personalizovanej terapii (CEVYPET)", kód: 26220120053 a "Identifikácia nových markerov $\checkmark$ diagnostickom paneli neurologických ochorení" spolufinancovanými zo zdrojov EÚ a Európskeho fondu regionálneho rozvoja.
\end{abstract}

The authors declare they have no potential conflicts of interest concerning drugs, products, or services used in the study.

Autoři deklarují, že $v$ souvislosti s předmětem studie nemají žádné komerční zájmy.

The Editorial Board declares that the manuscript met the ICMJE "uniform requirements" for biomedical papers.

Redakční rada potvrzuje, že rukopis práce splnil ICMJE kritéria pro publikace zasílané do biomedicínských časopisů.

\section{$\Xi^{\circ}$}

MVDr. Soňa Bálentová, Ph.D.

Institute of Histology and Embryology Jessenius Faculty of Medicine in Martin

Comenius University in Bratislava

Mala Hora 4

03601 Martin

Slovak Republic

e-mail: balentova@jfmed.uniba.sk

Submitted/Obdrženo: 7. 4. 2013

Accepted/Príijato: 23. 4. 2013 


\section{Background}

In the mammalian forebrain, the subventricular zone (SVZ) represents one of the two discrete regions with persistent proliferative activity. It is composed of stem cells, progenitor cells, ependymal cells and cell types of glial, endothelial and microglial origin. The fate of descendants of proliferating cells depends on their location. The SVZ progenitors migrate along the well-defined pathway, called the rostral migratory stream (RMS) towards to olfactory bulb $(\mathrm{OB})$ where they differentiate into granule or periglomerular interneurons and integrate to preexisting functional circuits [1-3]. Radiation-induced brain injury can damage the neuronal, glial and vascular compartments of the brain and may lead to anatomic and functional deficits. Research into irradiation effects has been mostly focused on studies of single-dose irradiation [4-7]. Single moderate (2-10 Gy) whole brain irradiation led to substantial loss of proliferating cells and immature neurons from the SVZ in a dose-dependent fashion up to several months after treatment; however, surviving cells have limited potential of SVZ repopulation or regeneration $[4,8]$. In the medical field, the leading mode of radiation delivery is fractionation, i.e. dividing radiation into multiple smaller doses to minimize any negative effect of radiation. The influence of dose, fractionation treatment, time of irradiation on late functional and histopathological changes have been derived from studies in rodents $[7,6]$. Fractiona-

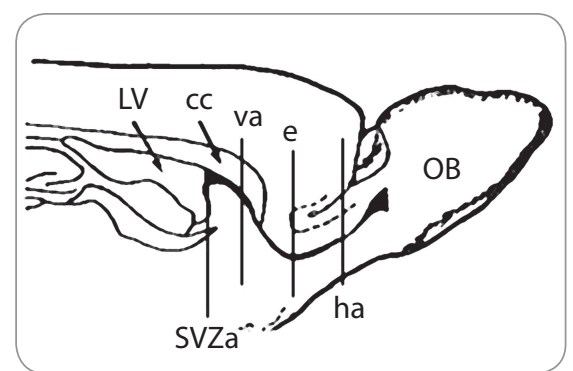

Fig. 1. Schematic sagittal view of the rat forebrain. Vertical lines point to the individual parts along the SVZ-OB axis, where the $\mathrm{Ki}-67^{+}$cells were counted [22].

SVZa - anterior horn of the subvetricular zone, cc - corpus callosum, LV - lateral ventricle, va - vertical arm, e - elbow, ha - horizontal arm of the RMS, OB - olfactory bulb ted treatment led to vascular structural changes, increased blood-brain barrier permeability, microglial activation, enhanced expression of astrocytes and high expression of inflammation-related molecules (cyclooxygenase; Cox, intercellular adhesion molecule-1; ICAM-1, tumor necrosis factor-alpha; TNF-a) up to six months post-irradiation [9-13].

In the present study, we investigated the alteration in spatio-temporal distribution of proliferating cells resident in adult SVZa and adjacent regions exposed to fractionated doses (the total dose of $3 \mathrm{~Gy}$ ) of gamma rays at different intervals after post-irradiation survival.

\section{Material and methods}

\section{Animals}

Adult male Wistar strain rats (SAV Dobrá Voda, SR) 7-8 months old at the start of the experiment and weighing approximately $380 \mathrm{~g}$, were used in this study. The animals were kept under standard conditions (temperature of $22-24{ }^{\circ} \mathrm{C}$, light-controlled environment with 12/12-h light/dark cycle) and provided with food and water ad libitum. The protocols for use of experimental animals were approved by the Animal Care and Use Committee, Jessenius Faculty of Medicine in Martin, Comenius University in Bratislava, Slovakia (approval number Ro 1663/08-221/3 for animal experiments).

\section{Irradiation}

For the irradiation procedure, the animals were anesthetized by i.p. injection of ketamine $(1-2 \mathrm{ml} / \mathrm{kg}$ of body weight) and a s.c. injection of xylasine $(0.1-0.2 \mathrm{ml} / \mathrm{kg}$ b.w.). The rats were whole-body irradiated using a ${ }^{60} \mathrm{Co}$ radiation source (apparatus TERAGAM 02 UJP, Prague, Czech Republic) at a dose rate of $1.86 \mathrm{~Gy} \times \mathrm{min}^{-1}$. The total radiation dose administered was $3 \mathrm{~Gy}$ of gamma rays (1 Gy $\times 3$ ) given at seven day intervals; the animals survived seven or 14 days after the last exposure (three animals at each time interval). Control animals were killed on day seven $(n=2)$ and day $14(n=2)$ after sham irradiation.

\section{Immunohistochemistry}

One to two weeks after irradiation, the animals were overdosed by inhala- tion of a mixture containing 3\% sevoflurane, $68 \% \mathrm{~N}_{2} \mathrm{O}$ and $30 \% \mathrm{O}_{2}$, and transcardially perfused with saline followed by fixative 4\% paraformaldehyde in $0.1 \mathrm{M}$ phosphate buffer (PB). Brains were immediately removed from the skull, postfixed overnight in the same fixative at $4{ }^{\circ} \mathrm{C}$ and cryoprotected in $30 \%$ sucrose for $18 \mathrm{~h}$. Tissue samples were covered with embedding medium (Killik, Bio Optica, Milano, Italy) and immediately frozen by rapid cooling boost in a cryobar (Shannon Cryotome E, Thermo Scientific Waltham, MA, USA). Serial sagittal $30 \mu \mathrm{m}$ frozen sections were cut, collected on lysine coated slides and air-dried. To minimize non-specific binding of the secondary antibody, sections were incubated for $1 \mathrm{~h}$ at room temperature (RT) in goat blocking solution (10\% goat serum, 1\% BSA, 0.5\% Tween 20 in PBS) and then covered overnight at $4{ }^{\circ} \mathrm{C}$ by rabbit anti-Ki-67 (Abcam, Cambridge, UK), a nuclear antigen that is expressed during the entire cell cycle except $\mathrm{G}_{0}$ stage. After rinsing, the sections were incubated for $2 \mathrm{~h}$ at RT with goat anti-rabbit secondary antibody labeled with Alexa Fluor 488 (1: 100, diluted in 0.3\% Triton X-100 and 1\% BSA in PBS, Molecular Probes, Eugene, OR, USA) and finally coverslipped with Fluoromount (Serva, Heidelberg, Germany). The slides were viewed with an Olympus FluoView FV10i confocal laser scanning microscope (Olympus, Japan) with $10 \times$ objective, equipped with Alexa Fluor 488 (excitation: $499 \mathrm{~nm}$; emission: $520 \mathrm{~nm}$ ). The image capture was performed with an Olympus Fluoview FV10-ASW software, version 02.01 (Olympus) and futher processed in Adobe Photoshop CS3 Extended, version 10.0 for Windows.

\section{Computer image analysis}

Quantitative assessment was performed in a standardized counting area which included $30 \mu \mathrm{m}$ thick serial sagittal sections from four different areas along the SVZ-OB axis i.e. anterior horn of the SVZ (SVZa), vertical arm, elbow and horizontal arm representing the individual parts of the RMS (Fig. 1). The vertical arm of the RMS began in anterior horn of brain lateral ventricles (LV) and curved ventrally between the corpus callosum and corpus 

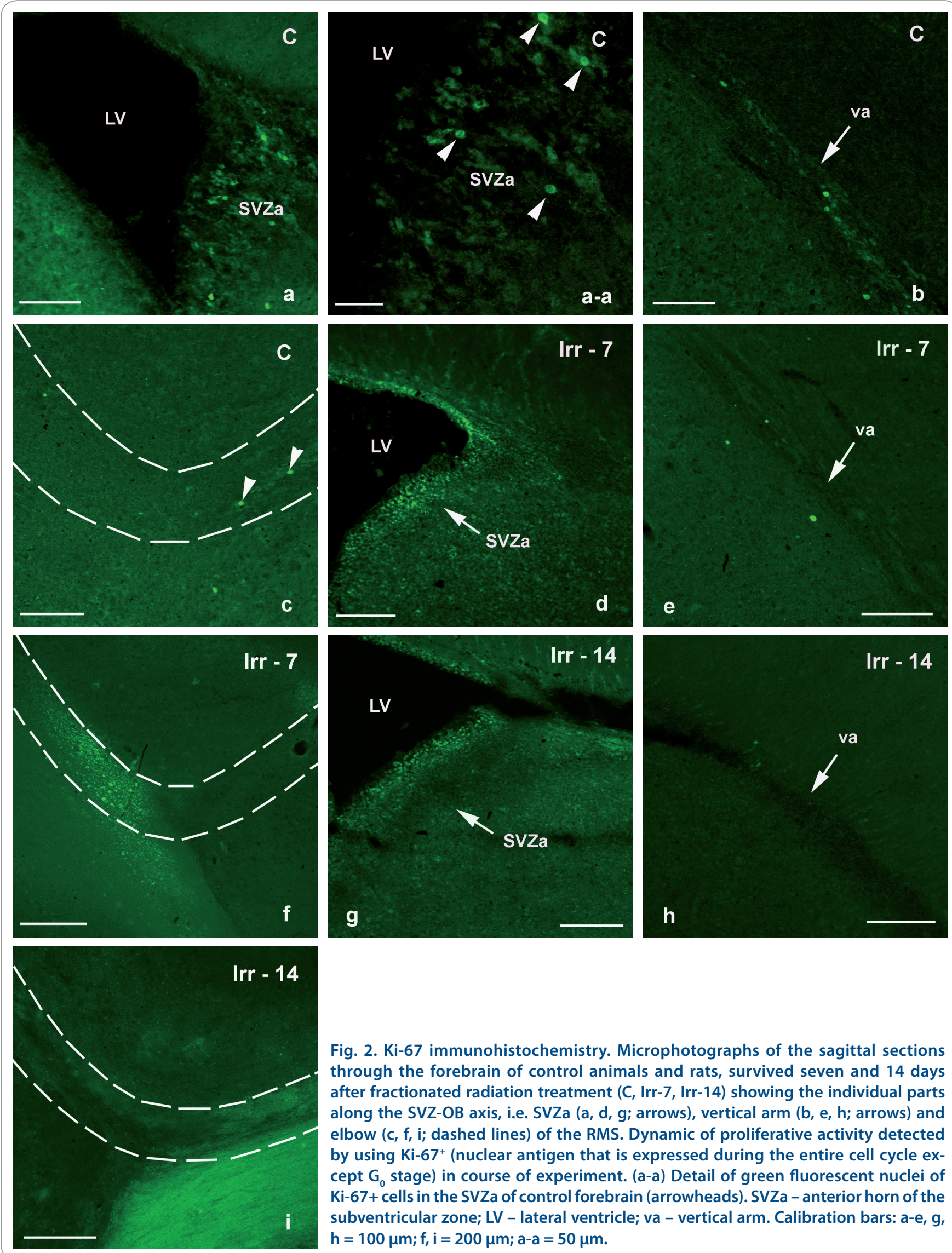

Fig. 2. Ki-67 immunohistochemistry. Microphotographs of the sagittal sections through the forebrain of control animals and rats, survived seven and 14 days after fractionated radiation treatment (C, Irr-7, Irr-14) showing the individual parts along the SVZ-OB axis, i.e. SVZa (a, d, g; arrows), vertical arm (b, e, h; arrows) and elbow ( $c, f, i$; dashed lines) of the RMS. Dynamic of proliferative activity detected by using $\mathrm{Ki}-67^{+}$(nuclear antigen that is expressed during the entire cell cycle except $\mathrm{G}_{0}$ stage) in course of experiment. (a-a) Detail of green fluorescent nuclei of $\mathrm{Ki}-67+$ cells in the SVZa of control forebrain (arrowheads). SVZa - anterior horn of the subventricular zone; LV - lateral ventricle; va - vertical arm. Calibration bars: a-e, g, $\mathrm{h}=100 \mu \mathrm{m} ; \mathrm{f}, \mathrm{i}=200 \mu \mathrm{m} ; \mathrm{a}-\mathrm{a}=\mathbf{5 0} \mu \mathrm{m}$. 


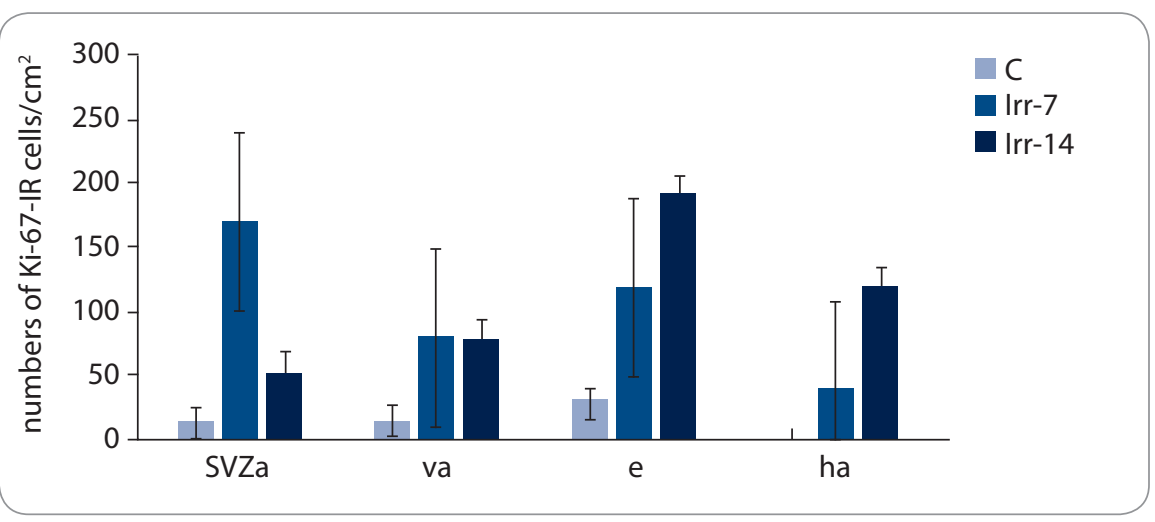

Fig. 3. Distribution of proliferating cells in individual parts along the SVZ-OB axis in the forebrain of control animals and rats, survived seven and 14 days after fractionated radiation treatment (C, Irr-7, Irr-14; $\overline{\mathbf{x}} \pm$ SEM).

striatum. Then, the RMS turned in a prominent angle, the elbow located half the distance from the rostral tip of the LV to the $O B$ and the horizontal arm, which presents the rostral half of the RMS. The numbers of Ki-67-positive cells (Ki-67+; green fluorescent nuclei) were counted in each stained section throughout the RMS (10-15 sections per animal). Quantitative analysis was performed using ImageJ software $(\mathrm{NIH}$, Bethesda, $\mathrm{MD}$, USA), a public domain image processing and analysis program allowing segmentation, thresholding and analysis to obtain information regarding particle size and numbers. The results were displayed as the total numbers of labeled $\mathrm{Ki}-67^{+}$ cells per $\mathrm{cm}^{2}$.

\section{Statistical analysis}

Data were analyzed using ANOVA one-way analysis followed by a Tukey-Kramer test comparison and presented as mean \pm standard error (SEM).

\section{Results}

Ki-67 immunohistochemistry demonstrates the RMS as a regularly shaped cord composed of highly or more weakly packed proliferating $\mathrm{Ki}-67^{+}$cells that are distinguishable from the surrounding brain parenchyma (Fig. 2). Image analysis of brain sections taken from control animals showed non-significant changes along the SVZ-OB axis. The highest value was seen in the elbow $\left(31.2 \pm 12.2 / \mathrm{cm}^{2}\right)$, and virtually no proliferation capacity was found in the horizontal arm. Massive distribution of $\mathrm{Ki}-67^{+}$cells was found in animals, survived seven days after irradiation with maximum in the SVZa (172 \pm 144 vs C: $15.8 \pm 5.2$ ) followed by decline in the vertical arm $(81.4 \pm 69.4$ vs C: $16.5 \pm 3.5)$ replaced by increase in the elbow (119.4 \pm 48.7 vs C: $31.2 \pm 12.2)$ and ultimate decrease in the horizontal arm (40.8 \pm 26.1$)$. In the group, survived 14 days after radiation treatment was seen the highest increase in the elbow $(191.9 \pm 67.2$ vs C: $31.2 \pm 12.2)$. After that, the rate of proliferation was decreased (ha: $119.8 \pm 60.1$ vs Irr-7: $40.8 \pm 26.1$ ); however, it still surpassed the values in the SVZa and vertical arm (SVZa: Irr-14: $53.6 \pm 12.1$; va: $78.5 \pm 16.9)$.

\section{Discussion}

Quantitative image analysis showed difference in spatio-temporal distribution of proliferating cells which reside in the SVZ-OB axis (Fig. 3). During the entire experiment, proliferative activity increased, and the highest distribution was seen in the rostral parts of the RMS. The proliferative response may represent the recruitment of a relatively quiescent stem cell population, and this cellular input was seen after fractionated radiation treatment $[14,15]$. However, we found discrepancy between our findings and data published before. All counted parts were changed during the entire experiment, and the most expressive changes were seen in the elbow and horizontal arm of the RMS. In our previous works $[16,17]$, we were concerned with radiation-induced alterations in proliferation dynamics of cells along the
RMS, labeled with exogenous proliferative marker 5-bromo-2'-deoxyuridine (BrdU). Investigation in the course of eighty days after single exposure showed that after initial steep decline in all counted parts, short-term increase in caudal parts of the RMS followed up to subsequent decrease close to control values at the end of the experiment. Recently, we have published data from a concurrent study that dealt with radiation-induced alterations in distribution of proliferating and glial cells in selected hippocampal regions [18]. Immunohistochemical labeling for $\mathrm{Ki}-67$ in two subregions, cornu ammonis region 1 (CA1) and cornu ammonis region 3 (CA3), showed (up to 90 days after fractionated irradiation) that proliferating cells with neuronal features reside in the stratum pyramidale and neighboring layers are susceptible to irradiation. The most prominent increase was found in the group that survived 30 days after irradiation replaced by significant decline until 60 days after treatment. Moreover, this is consistent with our following study concerned with the expression of SVZa derived young neurons in the same region up to 90 days after application of the same total radiation dose (3 Gy) [19]. Different dynamic of proliferation strongly depends on techniques used for radiation delivery. Cellular response to single exposure is rapid and massive, within hours after treatment, whereas the fractionated response is delayed and surpassed the end of radiation treatment. With a fractionated irradiation application, the first dose attacks predominantly the active proliferating cells, and cell death occurs several hours later. Apoptosis is replaced by restoration of mitotic activity as response to cell death, and the subsequent dose kills the cells that began to proliferate either spontaneously or in response to the cell loss of the previous day [20]. We may speculate that proliferative Ki-67 labeled cells arisen from SVZa during their migration from the caudal to the rostral part of the RMS die, cease to proliferate or accumulate due to slackening of migration.

Earlier studies showed depletion of cells of the SVZa rather than their 
short-term overdistribution $[8,14]$. This could play a major role in radiation-induced late effects, and it was suggested that if the restoration of SVZ fails, a gradual decline in the glial cells may lead finally to radiation necrosis. This could be important from a medical perspective since the doses used in radiotherapy of brain tumors are often much larger than the levels needed to eliminate neurogenesis [21]. Further research should clarify whether depletion of progenitors from the SVZ could contribute to complications of therapeutic brain irradiation.

\section{Conclusion}

Obtained results confirm previous findings about effect of fractionated treatment on density of proliferating cells resides adult rat forebrain. Regardless of the fact that short-term effect of ionizing radiation on the brain parenchyma does not have such negative prognosis, there is a potential risk to development of late symptoms. Take to account that the most important factor in radiation oncology is dose tolerance limit for normal tissue to therapeutic radiation, outputs taken from animal studies should be crucial for development of novel therapeutic approaches. Therefore, it is necessary to create prevention strategies to avoid irreversible effects in clinical radiotherapy.

\section{Acknowledgements}

The authors are grateful to colleagues from the Department of Radiotherapy and Oncology of the Martin University Hospital for technical assistance with the irradiation. We would like to express our thanks to Mrs. M. Kondeková, Mrs. A. Rešetárová and Mrs. Z. Cetlová for their excellent technical assistance.

\section{References}

1. Abrous DN, Koehl M, Le Moal M. Adult neurogenesis: from precursors to network and physiology. Physiol Rev 2005; 85(2): 523-569.

2. Carleton A, Petreanu LT, Lansford R et al. Becoming a new neuron in the adult olfactory bulb. Nat Neurosci 2003; 6(5): 507-518.

3. Lledo PM, Alonso M, Grubb MS. Adult neurogenesis and functional plasticity in neuronal circuits. Nat Rev Neurosci 2006; 7(3): 179-193.

4. Amano T, Inamura T, Wu CM et al. Effects of single low dose irradiation on subventricular zone cells in juvenile brain. Neurol Res 2002; 24(8): 809-816.

5. Lazarini F, Mouthon MA, Gheusi G et al. Cellular and behavioral effects of cranial irradiation of the subventricular zone in adult mice. PLoS One 2009; 4(9): e7017.

6. Mizumatsu S, Monje LM, Morhardt DR et al. Extreme sensitivity of adult neurogenesis to low doses of X-irradiation. Cancer Res 2003; 63(14): 4021-4027.

7. Peissner W, Kocher M, Treuer $\mathrm{H}$ et al. lonizing radiation-induced apoptosis of proliferating stem cells in the dentate gyrus of the adult rat hippocampus. Mol Brain Res 1999; 71(1): 61-68.

8. Tada E, Yang C, Gobbel GT et al. Long-term impairment of subependymal repopulation following damage by ionizing radiation. Exp Neurol 1999; 160(1): 66-77.

9. Cicciarello R, d'Avella D, Gagliardi ME et al. Time-related ultrastructural changes in an experimental model of whole brain irradiation. Neurosurgery 1996; 38(4): 772-779.

10. Gaber MW, Sabek OM, Fukatsu K et al. Differences in ICAM-1 and TNF-a expression between high single frac- tions and fractionated irradiation in mouse brain. Int J Radiat Biol 2003; 79(5): 359-366.

11. Yuan $\mathrm{H}$, Gaber MW, Boyd K et al. Effects of fractionated radiation on the brain vasculature in a murine model: blood-brain barrier permeability, astrocyte proliferation, and ultrastructural changes. Int J Radiat Oncol Biol Phys 2006; 66(3): 860-866.

12. Wilson CM, Gaber MW, Sabek OM et al. Radiation-induced astrogliosis and blood-brain barrier damage can be abrogated using anti-TNF treatment. Int J Radiat Oncol Biol Phys 2009; 74(3): 934-941.

13. Zhou H, Liu Z, Liu J et al. Fractionated radiation-induced acute encephalopathy in a young rat model: cognitive dysfunction and histologic findings. AJNR Am J Neuroradiol 2011; 32(10): 1795-1800.

14. Shinohara C, Gobbel GT, Lamborn KR et al. Apoptosis in the subependyma of young adult rats after single and fractionated doses of X-rays. Cancer Res 1997; 57(13): 2694-2702. 15. Philippo H, Winter EA, van der Kogel AJ et al. Recovery capacity of glial progenitors after in vivo fission-neutron or $\mathrm{X}$ irradiation: age dependence, fractionation and low-dose-rate irradiations. Radiat Res 2005; 163(6): 636-643.

16. Bálentová S, Račeková E, Martončíková M et al. Cell proliferation in the adult rat rostral migratory stream following exposure to gamma irradiation. Cell Mol Neurobiol 2006; 26(7-8): 1129-1137.

17. Bálentová S, Račeková E, Mišúrová E. Effect of low dose irradiation on proliferation dynamics in the rostral migratory stream of adult rats. Folia Biol (Prague) 2007; 53(3): 74-78.

18. Bálentová S, Hajtmanová E, Kinclová I et al. Radiation-induced long-term alterations in hippocampus under experimental conditions. Klin Onkol 2012; 25(2): 110-116.

19. Bálentová S, Haitmanová E, Plevkova J et al. Fractionated irradiation-induced altered spatio-temporal cell distribution in the rat forebrain. Acta Histochem 2013; 115(4): 308-314. 20. Wojtowicz JM. Irradiation as an experimental tool in studies of adult neurogenesis. Hippocampus 2006; 16(3): 261-266.

21. Wong CS, Van der Kogel AJ. Mechanisms of radiation injury to the central nervous system: implications for neuroprotection. Mol Interv 2004; 4(5): 273-284.

22. Martončíková M. Rostral migratory stream of rat during postnatal development. Bratislava 2004: 47. 